\title{
Comparison between a soluble antigen-based ELISA and IFAT in detecting antibodies against Babesia canis in dogs
}

\author{
Comparação entre ELISA feito com antígeno solúvel e imunofluorescência \\ na detecção de anticorpos anti-Babesia canis em cães \\ Patrícia Iriê Furuta ${ }^{1}$; Tricia Maria Ferreira de Sousa Oliveira ${ }^{1}$; Márcia Cristina Alves Teixeira ${ }^{2}$; \\ Artur Gouveia Rocha ${ }^{1}$; Rosangela Zacarias Machado ${ }^{1}$; Mirela Tinucci-Costa ${ }^{2 *}$

\begin{abstract}
${ }^{1}$ Departamento de Patologia Veterinária, Faculdade de Ciências Agrárias e Veterinárias - FCAV, Universidade Estadual Paulista - UNESP

${ }^{2}$ Departamento de Clínica e Cirurgia Veterinária, Faculdade de Ciências Agrárias e Veterinárias - FCAV, Universidade Estadual Paulista - UNESP
\end{abstract}

Received September 22, 2008

Accepted August 18, 2009

\begin{abstract}
An available enzyme-linked immunosorbent assay (ELISA) was studied for the detection of anti- $B$. canis antibodies in the sera of dogs using, indirect fluorescent antibody test (IFAT) as a reference test. ELISA uses a soluble antigenic preparation of $B$. canis and the optimal dilutions of the antigen, serum and conjugate were determined by check board titration, using positive and negative reference serum. The soluble antigen preparation of $B$. canis merozoites was $10 \mu \mathrm{g} . \mathrm{mL}^{-1}$, with reference sera from positive and negative in a single dilution of 1:100, and conjugated to 1:4.000. A total of 246 serum samples were collected from dogs during the rabies vaccination campaign in Jaboticabal, São Paulo, Brazil and examined for the presence of antibodies against B. canis by ELISA and IFAT. Under these conditions, the average absorbance of negative serum was $0.129 \pm 0.025$, resulting in a cut-off value of 0.323 (ELISA level 3 ) and the average absorbance of positive reference serum was $2.156 \pm 1.187$. The serological positive samples tested for $B$. canis by ELISA and IFAT were $67.89 \%(\mathrm{n}=167)$ and $59.35 \%(\mathrm{n}=146)$, respectively. These results suggest that ELISA described may prove to be an effective serological test to diagnose canine babesiosis.
\end{abstract}

Keywords: Babesia canis, ELISA, IFAT, dogs.

\section{Resumo}

O presente trabalho estudou um ensaio imunoenzimático (ELISA) indireto para a detecção de anticorpos anti-Babesia canis no soro de cães, tendo a Reação de Imunofluorescência Indireta (RIFI), como teste de referência O antígeno utilizado no ELISA do presente estudo consistiu em uma preparação antigênica solúvel de merozoítas $B$. canis e as diluições ótimas do antígeno, soros e conjugado foram determinadas por titulação em bloco, utilizando soros de referência positivos e negativos. A preparação antigênica solúvel de $B$. canis ótima foi de $10 \mu \mathrm{g} \cdot \mathrm{mL}^{-1}$, com soros de referência positivos e negativos em uma única diluição de 1:100, e conjugado a 1:4.000. Um total de 246 amostras séricas foram colhidas em cáes, durante a campanha de vacinação anti-rábica em Jaboticabal, São Paulo, Brasil e a presença de anticorpos anti-B. canis foi avaliada pelo ELISA e RIFI. Nestas condiçóes, a média de absorbância dos soros de referência negativos foi de $0,129 \pm 0,025$, resultando em um ponto de corte de 0,323 (Nível de ELISA 3) e a média da absorbância dos soros de referência positivos foi de 2,156 $\pm 1,187$. As amostras com sorologia positiva para $B$. canis por ELISA e RIFI foram $67,89 \%(n=167)$ e $59,35 \%(n=146)$, respectivamente. Os resultados obtidos sugerem que o ELISA descrito revelou-se um teste sorológico eficaz no diagnóstico da babesiose canina.

Palavras-chave: Babesia canis, ELISA, IFAT, cães.

\footnotetext{
*Corresponding author: Mirela Tinucci-Costa

Departamento de Clínica e Cirurgia Veterinária, Faculdade de Ciências

Agrárias e Veterinárias - FCAV, Universidade Estadual Paulista - UNESP

Via de Acesso Prof. Paulo Donato Castellane, s/n, CEP 14884-900,

Jaboticabal - SP, Brasil; e-mail: mirelatc@fcav.unesp.br
} 


\section{Introduction}

Canine babesiosis is a tick-borne hemolytic disease caused by the intraerythrocytic parasites Babesia canis and Babesia gibsoni, which affects wild and domestic canids (BRANDÃO et al., 2003). Babesia canis vogeli has been described as another parasite affecting canids (FARWELL et al., 1982). In Brazil, Passos et al. (2005) described the detection and first molecular characterization of $B$. canis vogeli in dogs. The brown dog tick, Rhipicephalus sanguineus, is the main vector of $B$. canis, and is usually found in urban endemic areas (LABRUNA; PEREIRA, 2001).

Babesia canis can infect dogs of all ages and primarily affects erythrocytes where the parasite replication and subsequent cell lysis occur, but can involve multiple organs and can range from a relatively mild to a fatal peracute disease (LOBETTI, 1998). The disease is mainly characterized by hemolytic anemia but there are other variations such as fever, lethargy, anorexia, and splenomegaly (BOOZER; MACINTIRE, 2003).

The introduction of carriers in the non-endemic area is helped by international and interstate transportation. The presence of chronic asymptomatic animals in these areas could bring the disease to the surface with the vector. These animals can keep elevated titers for a long period (de VOS et al., 1987), however it is very complicated to find the parasite in this stage of the disease.

The direct diagnosis of Babesia infection in dogs is based on the identification of the parasite in stained blood smears, even though it is difficult to find the protozoan in carrier animals. Regarding the indirect diagnosis, indirect fluorescent antibody test (IFAT) is the serological method often used to diagnose the disease (DELL' PORTO et al., 1990; TRAPP et al., 2006). It is also used for detecting the carrier animals as well as those with clinical symptoms but not without limitations as it is negative in puppies aged less than three months or with early stages of infection. Enzyme-linked immunosorbent assay (ELISA) is commonly used for diagnosis of various parasitic diseases including babesiosis (MARTINOD et al., 1985). This technique was considered an advance in terms of sensitivity, specificity, and reproducibility for the detection of specific antibodies in bovine babesiosis (MACHADO et al., 1997). Some other techniques including complement fixation, polymerase chain reaction, and nested polymerase chain reaction are also used for the diagnosis of $B$. canis, even though the last two methods are expensive and time-consuming (CLEVELAND et al., 2004).

The purpose of this study was to develop and establish the appropriateness of ELISA using a soluble antigen preparation of $B$. canis in addition to investigating the frequency of canine babesiosis in Jaboticabal, State of São Paulo, Brazil, and to compare the results to IFAT.

\section{Materials and Methods}

\section{Source of Babesia canis}

A B. canis strain isolated by Hagiwara in a dog at HOVET FMVZ-USP, São Paulo, São Paulo State, Brazil, was utilized in this study. The isolate was maintained cryopreserved in liquid nitrogen in the Immunoparasitology at the FCAV - UNESP. The $B$. canis soluble antigen was prepared by the inoculation of the strain intravenously in a splenectomized four-month-old dog, serologically negative for hemoparasites. The temperature was monitored daily and microscopic examination of Giemsa stained blood smears was carried out three times a day to check the presence of parasites. The peak of parasitemia occurred on the fifth day after inoculation and the infected blood was collected with Alsever solution. As soon as the blood was collected, the animal received a blood transfusion and was treated with imidocarb (Imizol ${ }^{\oplus}$, Coopers) at $5 \mathrm{mg} \cdot \mathrm{kg}^{-1}$ SC. The infected blood was diluted in saline solution $0.85 \%(1: 4)$, while the erythrocytes lysate with ammonium chloride was used to release the merozoites (MACHADO et al., 1994). The B. canis free merozoites were disrupted by seven freezing $\left(-70{ }^{\circ} \mathrm{C}\right) /$ thawing $\left(37^{\circ} \mathrm{C}\right)$ cycles, and were then lyophilized and stored at $-70{ }^{\circ} \mathrm{C}$ until required for the ELISA test (MACHADO et al., 1994).

\section{Serum samples}

The 246 serum samples used to investigate the prevalence of canine babesiosis were randomly obtained during a rabies vaccination campaign in Jaboticabal, in the State of São Paulo, Brazil. The negative reference serum $(n=5)$, tested by IFAT, was serum taken from one dog before the inoculation and four puppies before they suckled colostrum. The positive reference group $(n=5)$ tested positive for B. canis by IFAT at 1:40 dilution.

\section{ELISA procedure}

The method used was the one described by Machado et al. (1997), with some modifications. In each well of the micro-ELISA plate (Nunclon ${ }^{\mathrm{TM}}$ Surface, Nunc, Denmark), $100 \mu \mathrm{L}$ soluble $B$. canis antigen diluted in a bicarbonate-carbonated $0.05 \mathrm{M} \mathrm{pH} 9.6$ buffer, was added. The protein concentration was adjusted to $5,10,15$, and $20 \mu \mathrm{g} \cdot \mathrm{mL}^{-1}$. After 12 hours incubation at $4{ }^{\circ} \mathrm{C}$, the excess of antigen was removed by three washes with $0.05 \%$ phosphate buffer saline (PBS) Tween-20. The plates were blocked with $200 \mu \mathrm{L}$ PBS Tween-20 containing 5\% skim milk for 90 minutes at $37^{\circ} \mathrm{C}$, to reduce the non-specific binding, being removed after incubation. Each serum sample was diluted (1:100) in PBS Tween-20 with $5 \%$ normal rabbit serum, added in each well and then incubated for 90 minutes at $37{ }^{\circ} \mathrm{C}$ and washed as described above. One hundred $\mu \mathrm{L}$ alkaline phosphatase conjugated anti-dog IgG (Sigma Chemical Co.) diluted 1:4000 was added to each well and then incubated for 90 minutes at $37^{\circ} \mathrm{C}$, and then washed. Finally an appropriate substrate $\mathrm{p}$-nitrophenyl phosphate (npp) diluted in dietanolamine buffer $\mathrm{pH} 9.8$ was added and after 30 minutes the absorbance at $405 \mathrm{~nm}$ was read using an ELISA reader (Dynex Technologies).

The values of the absorbance were grouped into ELISA levels (EL), which ranged from 0 (lowest level) to 9 (highest level), as described by Machado et al. (1997). The discriminating absorbance value (cut-off) was determined as being two times the mean absorbance value of the negative group, where readings above the cut-off value were considered positive. 


\section{IFAT procedure}

The slides containing fixed blood infected with $B$. canis merozoites were air dried and successive serum dilutions $(1: 40,1: 80,1: 160,1: 320,1: 640$, and 1:1280) were pipetted onto areas circumscribed with nail polish. The slides were incubated in a moist chamber at $37^{\circ} \mathrm{C}$ for 45 minutes and then washed 3 times with PBS for 5 minutes each time. The delimited areas were covered with $10 \mu \mathrm{L}$ of anti-dog $\operatorname{IgG}(\mathrm{KPL})$ labeled with fluorescein isothiocyanate at 1:30 dilution in PBS containing $0.01 \%$ Evans blue. The slides were then incubated and washed as described above, dried and mounted with buffered glycerin, $\mathrm{pH}$ 9.6, and covered with a cover slip. The slides were examined under a fluorescence microscope using a 40x objective (Olympus, BX-FLA). Those that had fluorescence in the entire periphery of the protozoa $(\geq 1: 40)$ were considered a positive titer for the reaction. In the negative reactions, the protozoa did not present fluorescence.

\section{Statistical analysis}

The specificity and the sensibility of the ELISA test were calculated according to Braile and Godoy (1999).

\section{Results}

\section{Standardization of ELISA}

Check board titrations showed an antigen concentration of $10 \mu \mathrm{g} \cdot \mathrm{mL}^{-1}$ in the carbonate buffer, $\mathrm{pH} 9.6$, as optimum. Serum samples were diluted at 1:100. The average absorbance of negative sera was $0.129 \pm 0.025$, resulting in a calculated cut-off value of 0.323 (EL 3). The average absorbance of positive sera was $2.156 \pm 1.187$, approximately 6.67 times greater than that obtained with non-infected sera.

Titers of antibodies against $B$. canis soluble antigen were determined in sera from $246 \mathrm{dogs}$. The results of the number of sera distributed through EL are shown in Figure 1. The estimated ELISA values demonstrated that $67.89 \%(n=167)$ of the dogs had EL 3 to 9, with only $32.11 \%(n=79)$ of the serum samples being negative for $B$. canis infection.

\section{Indirect Fluorescent Antibody Test - IFAT}

Results showed that 100 (40.65\%) of the 246 serum samples analyzed were negative and $146(59.35 \%)$ of the 246 serum were positive for B. canis antigen. Of the 146 reactive sera, $4(2.74 \%)$ presented final titration at $1: 40$ dilution; $8(5.48 \%)$ at $1: 80$; $14(9.59 \%)$ at $1: 160 ; 18(12.33 \%)$ at $1: 320 ; 14(9.59 \%)$ at $1: 640$; and 88 serum samples $(35.77 \%)$ at 1:1.280 dilution. Therefore the highest percentage of reactive sera was found in the final titration range of 1:1280. Figure 2 illustrates the number of positive sera classified by reactivity with fluorescence intensity.

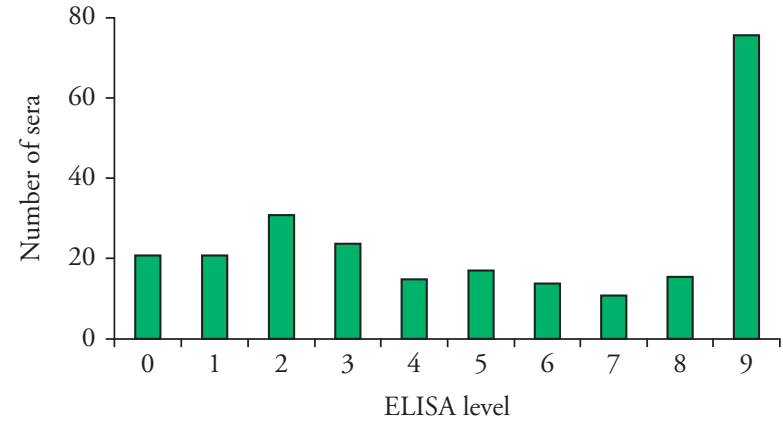

Figure 1. Number of sera from dogs $(\mathrm{n}=246)$ raised in Jaboticabal, São Paulo State, screened by ELISA against B. canis soluble antigen and plotted by ELISA level (EL).

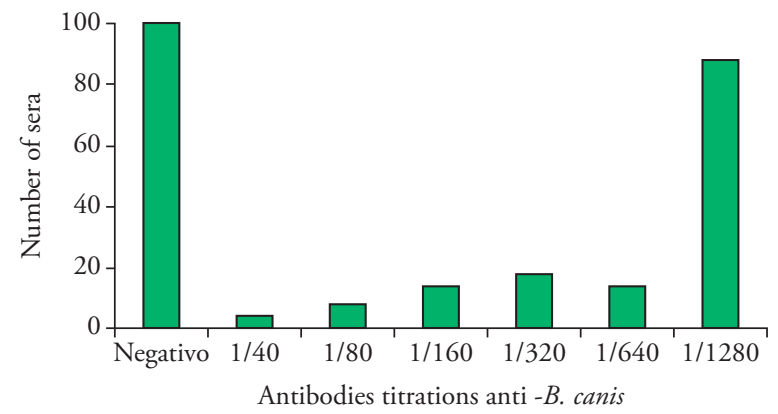

Figure 2. Number of sera from dogs $(\mathrm{n}=246)$ raised in Jaboticabal, Sáo Paulo State, against $B$. canis antigen, with reactivity by IFAT.

\section{Co-positive and co-negative serum samples tested by IFAT and ELISA}

The correlation between results obtained by IFAT and ELISA (Table 1) on anti-B. canis detection antibodies showed that $27.64 \%$ (68/246) were co-negative and $54.88 \%$ (135/246) were co-positive for the serological tests. A total of $67.89 \%$ (167/246) were positive by ELISA and 59.35\% (146/246) were positive by IFAT.

\section{Statistical analysis}

The specificity and the sensibility of the ELISA calculated were respectively 68.0 and $92.5 \%$, the kappa value was 0.63 and accuracy $82.5 \%$.

\section{Discussion}

The intraerythrocytic protozoan Babesia canis is one of the species that cause canine babesiosis. It has been studied worldwide and its prevalence and geographic variations depend on the vector distribution. The serological diagnoses normally used are IFAT and ELISA. The ELISA described in this paper is based on the use 
Table 1. Number of co-positive and co-negative sera in a total of 260 dog sera tested by IFAT and ELISA at 1:40 and 1:100 dilutions, respectively, against $B$. canis antigen.

\begin{tabular}{ccccc}
\hline \multirow{2}{*}{ ELISA } & IFAT & Positive & Negative & \multirow{2}{*}{ Total } \\
\cline { 3 - 5 } & & Number (\%) & Number (\%) & 167 \\
& Positive & $135(54.88)$ & $32(13.01)$ & 79 \\
& Negative & $11(4.47)$ & $68(27.64)$ & 246 \\
Total & 146 & 100 & 246 \\
\hline
\end{tabular}

Indice Kappa 0.73.

of reference sera to clearly define the difference between negative and positive sera and to calibrate ELISA absorbance as a score over a wide range of antibody levels. Furthermore, the antigenic preparation was produced using a very simple methodology and required little material manipulation at a very low cost. This technique has been used to detect antibodies against Babesia canis, B. gibsoni, B. bovis, B. bigemina, and B. equi in experimentally and naturally infected animals (MARTINOD et al., 1986; CHANG; TU, 1992; MACHADO et al., 1997; O’DONOGHUE et al., 1985; BALDANI et al., 2004).

The results in this study confirmed that a soluble antigen prepared from infected erythrocytes could be used in a sensitive ELISA to detect antibodies to $B$. canis. As well as this, other studies with another species of Babesia have used the experimental infection on splenectomized animals to investigate antibodies by ELISA (WEILAND, 1986; MACHADO et al., 1994; ARAÚJO et al., 1998; MOLLOY et al., 1998; KUMAR et al., 2003).

In this study, the $B$. canis antigen standardization established an ideal concentration of $5 \mu \mathrm{g} \cdot \mathrm{mL}^{-1}$, lower than $20 \mu \mathrm{g} \cdot \mathrm{mL}^{-1}$ used in a B. gibsoni soluble antigen from splenectomized dogs (CHANG and TU, 1992). This variation of the protein concentration suggests that the quality of the antigen is very significant. Good antigenic preparations of intracellular parasites are difficult to produce, particularly due to the presence of host contaminating components, such as red blood fragments. These contaminants can result in a nonspecific reaction on standardization of immunological assays.

The serological test frequently used to detect specific antibodies against canine babesiosis is IFAT; however this may have some limitations in endemic areas and be negative in very young animals or early infection (BOOZER; MACINTIRE, 2003). In previous studies, IFAT was considered a technique that had a high sensibility and moderate specificity because of cross-reactivity between Babesia species (ANDERSON et al., 1980). The possible cross-reactivity can be attributed to antigenic stimulation in the production of antibodies capable of reacting with similar antigens, or antigens shared by other protozoan. Furthermore, standardization is difficult considering the subjective judgment of the reader (BOSE et al., 1995; BRUNING, 1996).

The ELISA test can analyze a large number of samples simultaneously and the absorbance can be read automatically in an ELISA reader. There are not many studies of the humoral response in sera from dogs in Brazil, using ELISA for diagnosis of canine babesiosis. Most of the results have been obtained using IFAT. In previous Brazilian studies, the seropositive dogs for B. canis were between 36-73.5\% (DELL' PORTO et al., 1990; TRAPP et al. 2006). These results demonstrate a significant difference in relation to ours $(67.89 \%)$ possibly because of the geographic region, the incidence of Rhipicephalus sanguineus, individual response to hemoparasites, and largely different methodologies used to diagnose canine babesiosis. The ELISA test has been also used to diagnose the illness; a prevalence of $35 \%$ was recorded by MARTINOD et al. (1986), compared with $67.89 \%$ recorded in our study. Besides the different results, there are different ways of obtaining the soluble antigen of B. canis used in this serological test: the in vitro culture (MARTINOD et al., 1986) as well as the experimental infection in splenectomized dogs.

A great difference was observed when comparing the results found in ELISA and IFAT. ELISA showed that $67.89 \%$ of the samples analyzed were positive, as compared to $59.35 \%$ detected by IFAT for the same serum samples. There was statistical correlation between the two tests, but the results suggest that ELISA has higher sensitivity than IFAT, possibly because of the elevated surface antigen exposition of the organelles of the protozoan.

In conclusion, the ELISA system developed for the detection of anti-B. canis IgG antibodies and the method for soluble antigen production could be appropriated for serological diagnosis by ELISA of canine babesiosis, indicating the infection in dogs.

\section{References}

ANDERSON, J. F.; MAGNARELLI, L. A.; SUlZER, A. J. Canine babesiosis: indirect fluorescent antibodies test for a North American isolate of Babesia gibsoni. American Journal of Veterinary Research, v. 41, p. 2102-2105, 1980.

ARAÚJO, F. R. et al. Comparison between enzyme-linked immunosorbent assay, indirect fluorescent antibody and rapid conglutination tests in detecting antibodies against Babesia bovis. Veterinary Parasitology, v. 74, n. 2-4, p. 101-108, 1998.

BALDANI, C. D. et al. An enzyme-linked immunosorbent assay for the detection of IgG antibodies against Babesia equi in horses. Ciência Rural, v. 34, n. 5, p. 1525-1529, 2004.

BRAILE, D. M.; GODOY, M. F. Teste de diagnóstico - versão 1999. Disponível em:<http://www.braile.com/pesqcien.htm>. Acesso em: 12 março 2003.

BRANDĀO, L. P.; HAGIWARA, M. K.; MYASHIRO, S. I. Humoral immunity and reinfection resistance in dogs experimentally inoculated with Babesia canis and either treated or untreated with imidocarb dipropionate. Veterinary Parasitology, v. 114, n. 4, p. 253-265, 2003.

BÖSE, R. et al. Current state and future trends in the diagnosis of babesiosis. Veterinary Parasitology, v. 57, n. 1-3, p. 61-74, 1995. 
BOOZER, A. L.; MACINTIRE, D. K. Canine babesiosis. Veterinary Clinics of Small Animal, v. 33, n. 4, p. 885-904, 2003.

BRUNING, A. Equine piroplasmosis an update on diagnosis, treatment and prevention. British Veterinary Journal, v. 152, n. 2, p. 139-151, 1996.

CHANG, G. N.; TU, C. H. A serological survey of canine babesiosis in Taiwan. Journal of the Chinese Society of Veterinary Science, v. 18, p. 125-131, 1992.

CLEVELAND, C. W.; PETERSON, D. S.; LATIMER, K. S. An overview of canine babesiosis. Disponível em: $<$ http://www.vet.uga.edu/ vpp/clerk/Cleveland>. Acesso em: 10 abril 2004.

de VOS, A. J.; DALGLIESH, R. J.; CALLOW, L. L. Babesia In: SOULSBY, E. J. L. Immune responses in parasitic infections: immunology, immunopathology, and immunoprophylaxis. Florida: CRC Press, 1987. p. 183-222.

DELL'PORTO, A.; OLIVEIRA, M. R.; MIGUEL, O. Babesia canis in stray of city of Sáo Paulo. Comparative studies between the clinical and hematological aspects and the indirect fluorescent antibody test. Revista Brasileira de Parasitologia Veterinária, v. 2, n. 1, p.37-40, 1993.

FARWELL, G. E.; LeGRAND, E. K.; COBB, C. C. Clinical observation on Babesia gibsoni and Babesia canis infection in dogs. Journal of the American Veterinary Medical Association, v. 180, n. 5, p. 507-511, 1982.

KUMAR, S. et al. Standardization and comparison of serial dilution and single dilution enzyme linked immunosorbent assay (ELISA) using different antigenic preparations of the Babesia (Theileria) equi parasite. Veterinary Research, v. 34, n. 1, p. 71-83, 2003.

LABRUNA, M. B.; PEREIRA, M. C. Carrapato em cães no Brasil. Clínica Veterinária, n. 30, p. 24-32, 2001.

LOBETTI, R. G. Canine Babesiosis. The Compendium on Continuing Education for the Practicing Veterinarian, v. 20, n. 4, p. 418-430, 1998.
MACHADO, R. Z. et al. Isolation of Babesia bigemina and Babesia bovis merozoites by ammonium chloride lysis of infected erythrocytes. Brazilian Journal of Medical and Biological Research, v. 27, n. 11, p. 2591-2598, 1994.

MACHADO, R. Z. et al. An enzyme-linked immunosorbent assay (ELISA) for the detection of antibodies against Babesia bovis in cattle. Veterinary Parasitology, v. 71, n. 1, p. 17-26, 1997.

MARTINOD, S.; BROSSARD, M.; MOREAU, Y. Immunity of dogs against Babesia canis, its vector tick Dermacentor reticulatus, and Ixodes ricinus in endemic area. Journal of Parasitology, v. 71, n. 3, p. 269-273, 1985.

MARTINOD, S.; LAURENT, N.; MOREAU, Y. Resistance and immunity of dogs against Babesia canis in an endemic area. Veterinary Parasitology, v. 19, n. 3-4, p. 245-254, 1986.

MOLLOY, J. B. et al. Development of an enzyme-linked immunosorbent assay for detection of antibodies to Babesia bigemina in cattle. Parasitology Research, v. 84, n. 8, p. 651-656, 1998.

O'DONOGHUE, P. J. et al. The detection of IgM and IgG antibodies against Babesia bigemina in bovine sera using semi-defined antigens in enzyme immunoassays. Veterinary Parasitology, v. 18, n. 1, p. 1-18, 1985.

PASSOS, L. M. F. et al. First molecular detection of Babesia vogeli in dog from Brazil. Veterinary Parasitology, v. 127, n. 1, p. 81-85, 2005.

TRAPP, S. M. et al. Seroepidemilogy of canine babesiosis and ehrlichiosis in a hospital population. Veterinary Parasitology, v. 140, n. 3-4, p. 223-230, 2006.

WEILAND, G. Species-specific serodiagnosis of equine piroplasma infections by means of complement fixation test (CFT), immunofluorescence (IIF), and enzyme-linked immunosorbent assay (ELISA). Veterinary Parasitology, v. 20, n. 1-3, p. 43-48, 1986. 